\title{
THERMAL MODELLING AND PERFORMANCE STUDY OF MODIFIED DOUBLE SLOPE SOLAR STILL
}

\author{
Ajaya Ketan Nayak', Rahul Dev ${ }^{2}$ \\ ${ }^{1}$ Assistant Professor, School of Mechanical Engineering, Kalinga Institute of Industrial Technology, Bhubaneswar, \\ Odisha-751024, India \\ ${ }^{2}$ Assistant Professor, Department of Mechanical Engineering, Motilal Nehru National Institute of Technology \\ Allahabad, Allahabad-211004, Uttar Pradesh, India. \\ *Corresponding author-Telephone: +91-9437842183, E-mail: ajaya.ketana@gmail.com
}

\begin{abstract}
Solar distillation is a process of producing purified drinking water from brackish water by using the heat of solar radiation as the feed to evaporate the impure water which on condensation gives the pure water. It is independent of electricity, a major portion of which is generated from fossil fuel causing environmental pollution and relies completely on renewable source of energy like solar radiation, thus making it environment friendly.

In this paper a modified double slope solar still (modified DSSS) has been designed by using Transparent Acrylic and opaque Fibre Reinforced Plastic (FRP) as its body material with two toughened glass covers. The basin and north wall of modified DSSS have been made by using FRP of thickness $(0.005 \mathrm{~m})$, whereas, its three sides (East, West and South walls) are made of transparent Acrylic sheet of thickness $(0.003 \mathrm{~m})$ equivalent to that of FRP for the same heat loss, which results in increased input solar radiation inside the solar still and improved performance but with low cost.

It is evident that, the inside space of solar still is filled with air and vapour molecules which can come in contact with inner surfaces of walls and glass covers. The vapour molecules close to the walls strike it due to molecular collisions and stick to it to release its heat for phase change from vapour to liquid during condensation process. Hence, five troughs (distillate collecting channels) have been placed at inside surfaces of all its walls and glass covers. The yield has been collected from all the sides of the solar still except north wall which acts heat absorber. The molecules which come in contact with north wall get additional heat from it and get evaporated.

In this paper, a thermal model has been developed to predict theoretically the performance of MDSSS for the climatic condition of MNNIT, Allahabad, India on $22^{\text {nd }}$ May 2014. Expressions for water and glass temperatures and hourly yield for the modified double slope solar distillation system have been derived analytically. It has been found that the total yield obtained from the MDSSS in a period of 24 hour is $16 \mathrm{Kg}$ of purified water from $25 \mathrm{Kg}$ of brackish water which is about twice of that obtained from conventional solar stills. Also the effect of solar radiation on the productivity of solar still has been analyzed.
\end{abstract}

Keywords: Equivalent Thickness, Molecular Collision, Double Slope Solar Still, Yield

\section{INTRODUCTION}

Pure drinking water is an important part of daily life of a human being. But now a day it is difficult to be obtained from natural resources due to alarmingly increasing water pollution. Though various modern water filtration technologies like RO and MF etc are available, still the major problem concerned with these technologies is that they rely upon electricity a major portion of which is generated from gas or coal based power plants, which also cause environmental pollution. Hence an environment friendly, economical and effective water purification technology like solar distillation is highly desirable for solving today's water scarcity problem.

The productivity of a solar still is dependent on various climatic as well as design parameters [1-4]. Dunkle [5] has mathematically analyzed the heat interactions inside the solar still. Tiwari et al. [6] have expressed the heat and mass transfer inside the solar still as a function of condensing cover inclination. An analytical thermal model has been developed by Dwivedi and Tiwari for Double Slope active solar still [7]. Shukla and Sorayan [8] have justified the agreement between thermal model and experimental results for a solar still for both summer and winter climatic condition. Characteristic equations have been developed for single slope solar still by Dev and Tiwari [9] for different water depth and inclinations. Dev [10] has analyzed so many passive and active solar distillation systems to formulate their characteristic equations.

The objective of this paper is to design a Modified Double Slope Solar Still (MDSSS) which replaces fiber reinforced plastic (FRP) by acrylic as the body material for the three 
side walls (East, West and South). The transparency of acrylic increases the input solar radiation in to the still. Hence, a thermal model has been developed to correlate the new design. It has been used to test theoretically the performance of MDSSS for the climatic condition of MNNIT,Allahabad India. The effect of solar radiation on the productivity of the MDSSS has been analyzed to compare the yield during summer and winter climatic conditions.

\section{EXPERIMENTAL SET UP}

Fig. 1 depicts the isometric view of experimental set up which is modeled using CATIA V5R18 software. MDSSS consists of a box shaped basin of base area $2 \mathrm{~m}^{2}$. The height of the solar still walls is $0.12 \mathrm{~m}$ at the East-West ends and $0.38 \mathrm{~m}$ at the centre. The base and North wall are made of FRP of $0.005 \mathrm{~m}$ thickness which are painted black from inside to increase absorptivity of solar radiation. Three side walls (East, West and South) are made of acrylic of $0.003 \mathrm{~m}$ thickness equivalent to that of FRP for same heat loss. Toughened glass is used as the building material for two glass covers of dimensions $1.03 \times 1.03 \times 0.004 \mathrm{~m}^{3}$ to ensure reliable and harmless operation .Two glass covers inclined at angle of $15^{\circ}$ are used to seal the top of the still. The purpose of maintaining this angle is to receive maximum irradiation for any position of sun and to guide the condensate under the combined effect of gravity, adhesion and cohesion forces. Brackish water is supplied in to the still through an inlet provided at the north wall. Five troughs have been placed at the inside surface of the walls and glass covers to collect the distillate and guide it in to the collecting jars placed outside. No condensate is obtained from north wall, as the vapour molecules striking it get additional heat from it.

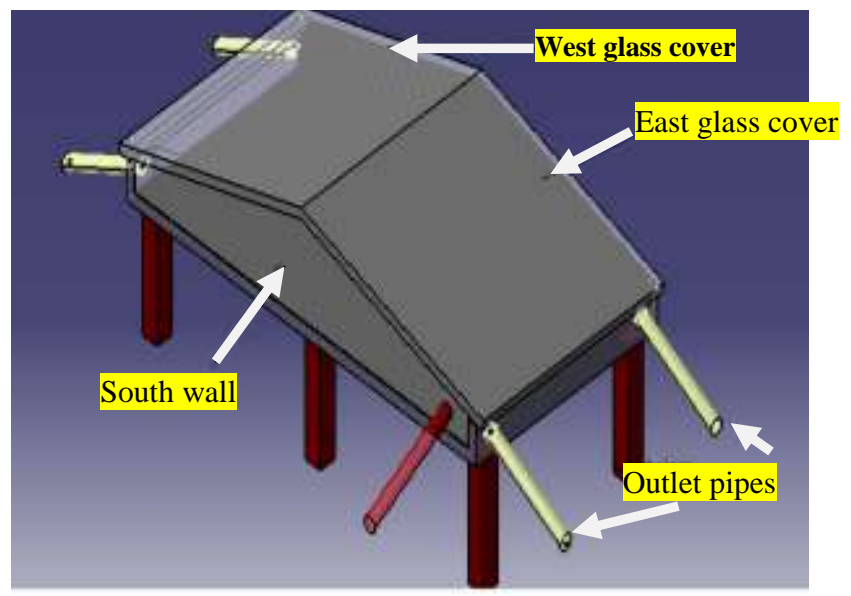

Fig.1. Isometric View of MDSSS

\section{METHODOLOGY}

Research methodology deals with detailed description of working principle (modified) and complete thermal model.

\subsection{Working Principle}

The space enclosed by the solar still consists of a large number of air and water vapor molecules. These molecules are in random motion and may come in contact with the inside surfaces of the walls and glass covers. Early in the morning when the sun rises solar radiation is incident on the water inside the still through the transparent acrylic walls. The temperature inside the still increases causing a rise in molecular kinetic energy. Hence, the molecules undergo rapid collision with each other. As a result the vapor molecules close to the walls stick to it and release heat through the process of condensation to undergo phase change from vapor to liquid state.

Hence, yielding starts very early unlike the conventional stills which produce distillate only when glass covers receive sufficient solar radiation (due to opaque FRP walls). As the sun moves toward west due south, more solar radiation enters through the walls and glass covers. A large fraction of this radiation is absorbed by the basin liner and the north wall due to high absorptivity. Heat is transferred from basin to water by convection which evaporates the water. The vapor molecules come in contact with the walls and glass covers through molecular collision and condensation process continues. The condensate is guided by the troughs to the collecting jars placed outside.

Various design and operational parameters have been listed in Table 1. The distillate obtained from the MDSSS has been calculated on hourly basis for the date of $22^{\text {nd }}$ May, 2014 for the climatic condition of MNNIT, Allahabad, India.

\subsection{Thermal Modeling}

The thermal model involves formulation of energy balance equations for different parts of the MDSSS based on the following assumptions.

i) MDSSS is sealed from vapor leakage.

ii) Zero temperature gradient is assumed within the water.

iii) Glass and basin materials posses negligible heat capacity.

iv) Heat transfer coefficients are temperature dependent.

v) A hypothetical vapor surface is assumed inside the still from which all the heat interactions to the condensing surfaces take place. 
Table 1: Design and operational parameters of MDSSS

\begin{tabular}{|c|c|c|}
\hline Sl.no & Type & Specification \\
\hline 1 & location & MNNIT, Allahabad, India \\
\hline 2 & $\begin{array}{l}\text { Specification of } \\
\text { location }\end{array}$ & $\begin{array}{l}25^{\circ} 23^{\prime} \mathrm{N}, 81^{\circ} 52^{\prime} \mathrm{E} \\
\text { altitude } 101 \mathrm{~m} \text { from sea } \\
\text { level }\end{array}$ \\
\hline 3 & Climate & warm and humid \\
\hline 4 & Orientation & East - west \\
\hline 5 & Body material & $\begin{array}{l}\text { Base and north wall made } \\
\text { of FRP, other three walls } \\
\text { of acrylic, east and west } \\
\text { glass covers of toughened } \\
\text { glass }\end{array}$ \\
\hline 6 & $\begin{array}{l}\text { Basin area and } \\
\text { colour }\end{array}$ & $2 \mathrm{~m}^{2}$, black \\
\hline 7 & $\begin{array}{l}\text { Thickness of } \\
\text { GRP }\end{array}$ & $0.005 \mathrm{~m}$ \\
\hline 8 & $\begin{array}{l}\text { Thickness of } \\
\text { acrylic }\end{array}$ & $0.003 \mathrm{~m}$ \\
\hline 9 & Height at ends & $0.12 \mathrm{~m}$ \\
\hline 10 & Height at centre & $0.38 \mathrm{~m}$ \\
\hline 11 & Toughened glass & $1.03 \times 1.03 \times 0.004 \mathrm{~m}^{3}$ \\
\hline 12 & Quantity of glass & 2 \\
\hline 13 & Inclination angle & $15^{0}$ \\
\hline 14 & $\begin{array}{l}\text { Colour of north } \\
\text { wall inside }\end{array}$ & Black \\
\hline 15 & $\begin{array}{l}\text { Number of inlet } \\
\text { to saline water }\end{array}$ & 1 \\
\hline 16 & $\begin{array}{l}\text { No. of outlets } \\
\text { connected with } \\
\text { trough at ends }\end{array}$ & 5 \\
\hline 17 & $\begin{array}{l}\text { Latent heat of } \\
\text { vaporization }(\mathrm{L})\end{array}$ & $2390 \times 10^{3} \mathrm{~J} / \mathrm{kg}$ \\
\hline 18 & Water depth & $1.25 \mathrm{~cm}$ \\
\hline 19 & $\begin{array}{l}\text { Specific heat of } \\
\text { water }\left(\mathrm{C}_{\mathrm{w}}\right)\end{array}$ & $4200 \mathrm{~J} / \mathrm{kgK}$ \\
\hline 20 & Mass of water(M) & $25 \mathrm{~kg}$ \\
\hline 21 & Wind velocity(v) & $0-20 \mathrm{~m} / \mathrm{s}$ \\
\hline 22 & $\mathrm{~K}_{\mathrm{FRP}}$ & $0.351 \mathrm{~W} / \mathrm{mK}$ \\
\hline 23 & $\mathrm{~K}_{\mathrm{g}}$ & $0.78 \mathrm{~W} / \mathrm{mK}$ \\
\hline 24 & $\mathrm{~K}_{\mathrm{AC}}$ & $0.2 \mathrm{~W} / \mathrm{mK}$ \\
\hline 25 & $\alpha_{b g}^{\prime}$ & 0.8 \\
\hline 26 & $\alpha_{\mathrm{g}}^{\prime}$ & 0.1 \\
\hline 27 & $\alpha_{\mathrm{wg}}^{\prime}$ & 0.6 \\
\hline 28 & $\varepsilon_{\mathrm{g}}$ & 0.8 \\
\hline 29 & $\varepsilon_{\mathrm{w}}$ & 0.95 \\
\hline 31 & $\mathrm{U}_{\mathrm{bw}}$ & $300 \mathrm{~W} / \mathrm{mK}$ \\
\hline 32 & $\alpha_{\text {bac }}^{\prime}$ & 0.77 \\
\hline 33 & $\alpha_{N g}^{\prime}$ & 0.7 \\
\hline
\end{tabular}

Energy balance equation for different components of MDSSS:

\section{a. For inner surface of north wall}

$$
\alpha_{N g}^{\prime} \cdot A_{N} \cdot I(t)_{g N}=h_{N v} \cdot A_{N} \cdot\left(T_{i N}-T_{v}\right)+h_{K F R P} \cdot A_{N}\left(T_{i N}-T_{o N}\right)
$$

\section{b. For outer surface of north wall}

$h_{\text {KFRP. }} A_{N}\left(T_{i N}-T_{O N}\right)=h_{0} A_{N}\left(T_{O N}-T_{a}\right)$

c. For inner surface of south wall

$\alpha_{S}^{\prime} \cdot A_{S} \cdot I(t)_{a c S}+h_{v S} \cdot A_{S} \cdot\left(T_{v}-T_{i S}\right)=h_{K a c r} \cdot A_{S} \cdot\left(T_{i S}-T_{o S}\right)$

d. For outer surface of south wall

$h_{\text {Kacr }} \cdot A_{S} \cdot\left(T_{i S}-T_{o S}\right)=h_{o} \cdot A_{S} \cdot\left(T_{o S}-T_{a}\right)$

e. For inner surface of east wall

$\alpha_{E}^{\prime} \cdot A_{E} \cdot I(t)_{a c E}+h_{v E} \cdot A_{E} \cdot\left(T_{v}-T_{i E}\right)=h_{\text {Kacr }} \cdot A_{E} \cdot\left(T_{i E}-T_{o E}\right)$

f. For outer surface of east wall

$h_{\text {Kacr }} \cdot A_{E} \cdot\left(T_{i E}-T_{o E}\right)=h_{o} \cdot A_{E} \cdot\left(T_{o E}-T_{a}\right)$

\section{g. For inner surface of west wall}

$\alpha_{\mathrm{W}}^{\prime} \cdot A_{W} \cdot I(t)_{a c W}+h_{v W} \cdot A_{W} \cdot\left(T_{v}-T_{i W}\right)=h_{\text {Kacr }} \cdot A_{W} \cdot\left(T_{i W}-T_{o W}\right)$

h. For outer surface of west wall

$h_{\text {Kacr }} \cdot A_{W} \cdot\left(T_{i W}-T_{o W}\right)=h_{o} \cdot A_{W} \cdot\left(T_{o W}-T_{a}\right)$

i. For inner surface of east glass cover

$\alpha_{g}^{\prime} \cdot A_{E} \cdot I(t)_{g E}+h_{v g E} \cdot A_{g E} \cdot\left(T_{v}-T_{g i E}\right)=h_{K g} \cdot A_{g E} \cdot\left(T_{g i E}-T_{g o E}\right)$

j. For outer surface of east glass cover

$h_{\mathrm{Kg}} \cdot A_{g E} \cdot\left(T_{g i E}-T_{g o E}\right)=h_{o} \cdot A_{g E} \cdot\left(T_{g o E}-T_{a}\right)$

k. For inner surface of west glass cover

$\alpha_{g}^{\prime} \cdot A_{g W} \cdot I(t)_{g W}+h_{v g W} \cdot A_{g W} \cdot\left(T_{v}-T_{g i W}\right)=h_{K g} \cdot A_{g W} \cdot$

$\left(\mathrm{T}_{\mathrm{giW}}-\mathrm{T}_{\mathrm{goW}}\right)$

1. For outer surface of west glass cover

$h_{\mathrm{Kg}} \cdot A_{g W} \cdot\left(T_{g i W}-T_{g o W}\right)=h_{o} \cdot A_{g W} \cdot\left(T_{g o W}-T_{a}\right)$

m. For vapour

$h_{w v} \cdot A_{b} \cdot\left(T_{w}-T_{v}\right)+h_{N v} \cdot A_{N}\left(T_{i N^{-}} T_{v}\right)=h_{v S} \cdot A_{S}\left(T_{v}-T_{i S}\right)+$ $h_{v E} \cdot A_{E} \cdot\left(T_{v}-T_{i E}\right)+h_{v W} \cdot A_{W} \cdot\left(T_{v}-T_{i W}\right)+h_{v g E} \cdot A_{g E} \cdot\left(T_{v}-\right.$ $\left.\mathrm{T}_{\mathrm{giE}}\right)+\mathrm{h}_{\mathrm{vgW}} \cdot \mathrm{A}_{\mathrm{gW}} \cdot\left(\mathrm{T}_{\mathrm{v}}-\mathrm{T}_{\mathrm{giW}}\right)$

\section{n. For water}

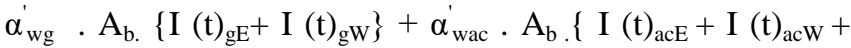
$\left.\mathrm{I}(\mathrm{t})_{\mathrm{acS}}\right\}+\mathrm{h}_{\mathrm{bw}} \cdot \mathrm{A}_{\mathrm{b}} \cdot\left(\mathrm{T}_{\mathrm{b}}-\mathrm{T}_{\mathrm{w}}\right)=(\mathrm{MC})_{\mathrm{w}} \cdot \frac{d T_{w}}{d t}+\mathrm{h}_{\mathrm{wv}} \cdot \mathrm{A}_{\mathrm{b}} \cdot\left(\mathrm{T}_{\mathrm{w}}-\mathrm{T}_{\mathrm{v}}\right)$ $+\mathrm{h}_{\mathrm{s} .} \mathrm{A}_{\mathrm{s}} \cdot\left(\mathrm{T}_{\mathrm{w}}-\mathrm{T}_{\mathrm{a}}\right)$ 


\section{o. For basin}

$\alpha_{\mathrm{bg}}^{\prime} \cdot \mathrm{A}_{\mathrm{b}} \cdot\left\{\mathrm{I}(\mathrm{t})_{\mathrm{gE}}+\mathrm{I}(\mathrm{t})_{\mathrm{gW}}\right\}+\alpha_{\mathrm{bac}}^{\prime} \cdot \mathrm{A}_{\mathrm{b}} \cdot\left\{\mathrm{I}(\mathrm{t})_{\mathrm{acE}}+\mathrm{I}(\mathrm{t})_{\mathrm{acW}}+\right.$

$\left.\mathrm{I}(\mathrm{t})_{\mathrm{acS}}\right\}=\mathrm{h}_{\mathrm{bw}} \cdot \mathrm{A}_{\mathrm{b}} \cdot\left(\mathrm{T}_{\mathrm{b}}-\mathrm{T}_{\mathrm{w}}\right)+\mathrm{h}_{\mathrm{ba}} \mathrm{A}_{\mathrm{b}}\left(\mathrm{T}_{\mathrm{b}}-\mathrm{T}_{\mathrm{a}}\right)$

Solution of the above equations gives a differential equation for water temperature as given below.

$$
\frac{d T_{w}}{d t}+a T_{w}=f(t)
$$

Solving the above equation we get the expression for water temperature:

$$
T_{w}=\frac{\overline{f(t)}}{a} \cdot\left(1-e^{-a t}\right)+T_{w o} \cdot e^{-a t}
$$

From $\mathrm{T}_{\mathrm{w}}$ the expressions for vapor temperature and west wall temperature have been derived as follows:

$$
\begin{gathered}
T_{v}=-\frac{A_{1}}{A_{2}}+\frac{T_{w}}{A_{2}} \\
T_{i W}=\left(\frac{R_{4}}{U_{4}}-\frac{h_{v W} \cdot A_{1}}{U_{4} \cdot A_{2}}\right)+\frac{h_{v W}}{U_{4} \cdot A_{2}} T_{w}
\end{gathered}
$$

Similar expressions for other temperatures have been obtained.

The hourly yield from West wall of the solar still has been given by the following equation

$$
\dot{M}_{e v W}=\frac{\dot{q}_{e v W} \times 3600}{L}=\frac{h_{e v W} \times 3600}{L}
$$

Where $h_{e v W}$ is the evaporative heat transfer coefficient between vapor and West wall, and $\mathrm{L}$ is the latent heat of water. Similarly the yield from other two walls and glass covers are obtained and their summation gives the total yield.

\section{RESULTS AND DISCUSSION}

The hourly variation of incident solar radiation on East and West glass Cover has been depicted in Fig.2. It is evident from the figure that, the incident solar radiation on East and West glass cover nearly remains same during noon hours (from 11:00 AM to 1:00 PM). Before noon the East glass cover is subjected to more solar radiation. As sun moves towards west incident radiation on west glass cover increases. The maximum solar radiation received by East and West glass cover is found to be $1083.7 \mathrm{~W} / \mathrm{m}^{2}$ and $1181 \mathrm{~W} / \mathrm{m}^{2}$ respectively.

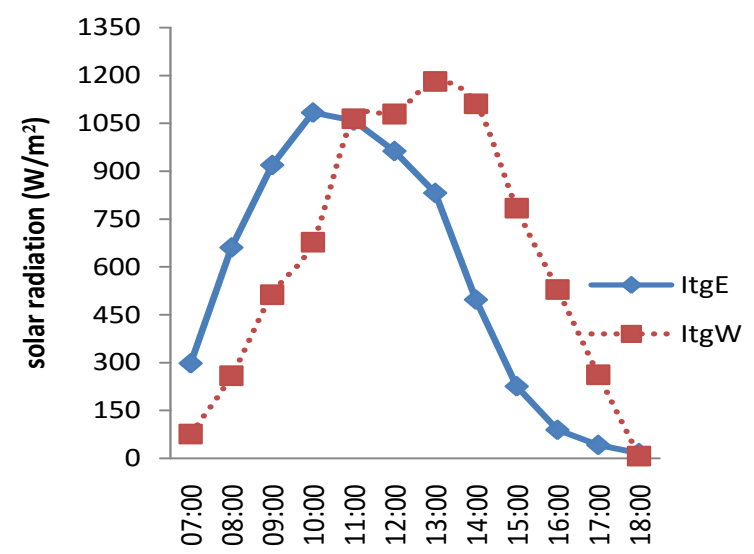

Time (h)

Fig. 2. Solar radiation variation on East and West glass cover on May 22, 2014, at MNNIT,Allahabad

Fig. 3 shows variation of ambient, water, and vapor temperature on hourly basis. The temperature of water is always greater than the vapor temperature which is more than the ambient . The maximum basin water temperature is found to be $82^{\circ} \mathrm{C}$ at $02: 00 \mathrm{PM}$. The basin water does not convect out the heat rapidly and heat is stored inside it. This stored heat helps in producing distilled water during night time when solar radiation is not available. Fig.4 shows the hourly variation of total distillate obtained from walls and glass covers of MDSSS for a water depth of $1.25 \mathrm{~cm}$. From the figure we can observe that amount of yield obtained gradually increases, becomes maximum during noon hour and then decreases. The total yield obtained from the MDSSS (from walls and glass covers) for a water depth of $1.25 \mathrm{~cm}$ in a period of 24 hours is $16 \mathrm{Kg}$, which is more than that obtained from conventional solar stills with FRP walls. Fig.5. compares the yield obtained during summer and winter climatic conditions. It is evident from the figure that, the yield obtained during the month of July is higher than that obtained during January. It is due to high ambient temperature and affluent solar radiation prevailing during summer condition. Total distillate obtained from the MDSSS in 24 hour on $23^{\text {rd }}$ January 2014 is $5.6 \mathrm{Kg}$ whereas that obtained during month of July is $13 \mathrm{Kg}$. from $25 \mathrm{Kg}$ of brackish water.

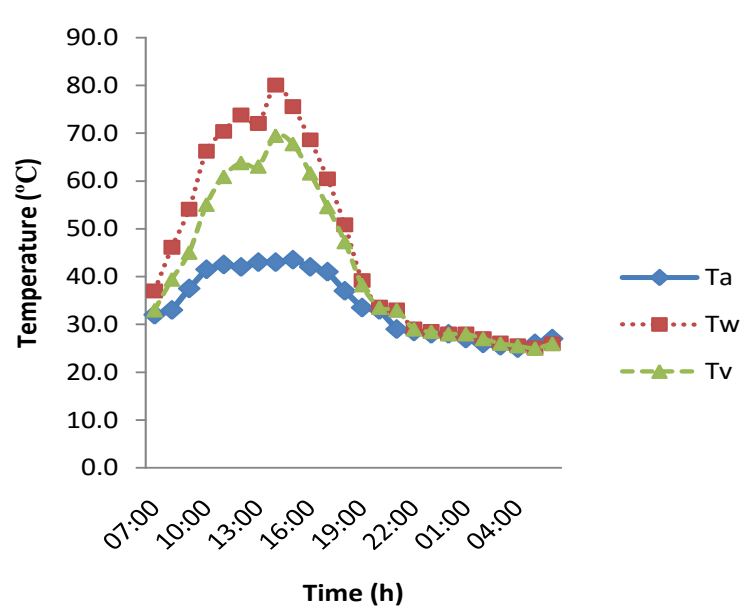

Fig.3. Temperature variation (hourly) of water, ambient and vapor on May 22,2014 at MNNIT,Allahabad 


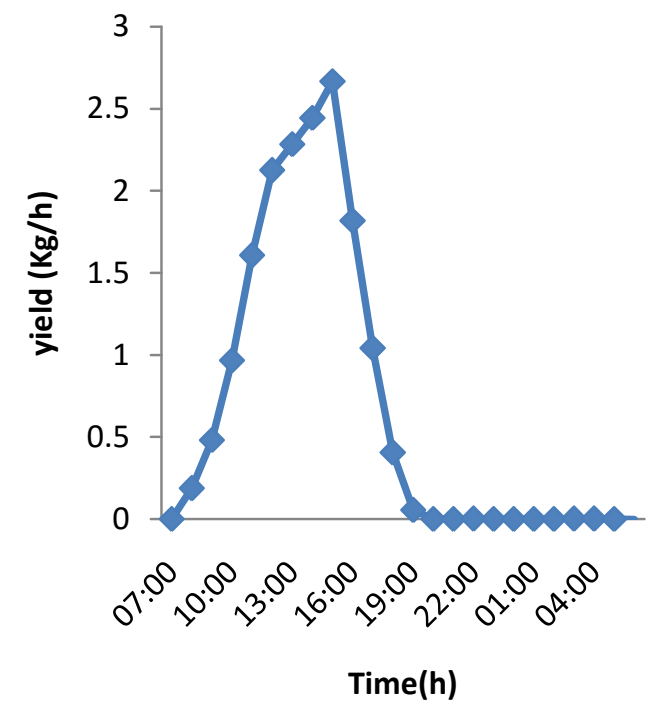

Fig.4. variation (hourly) of distillate on May 22, 2014 at MNNIT,Allahabad

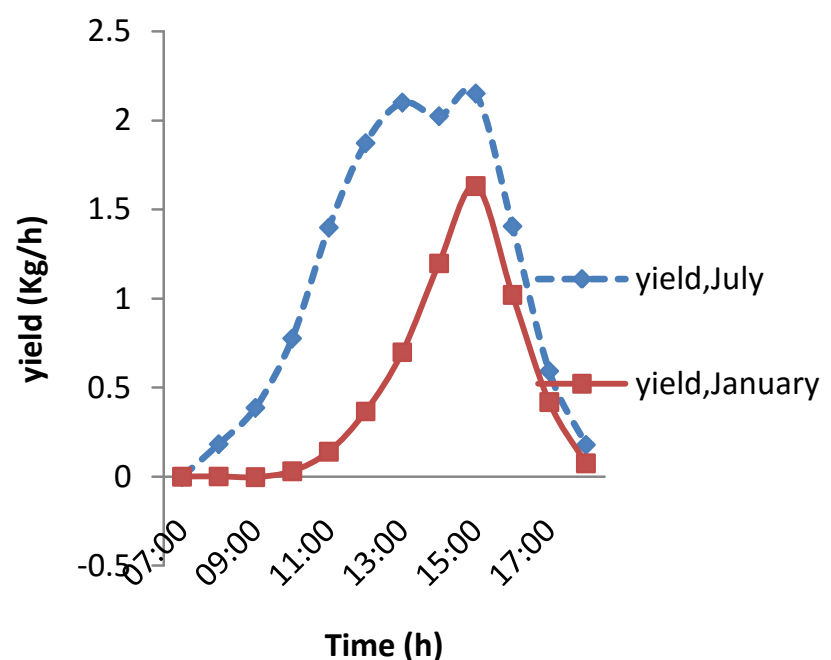

Fig.5. comparison of hourly yield on January 23, 2014 and July 22,2014

\section{CONCLUSION}

On the basis of above analysis, it is being observed that more yield (about double to that of conventional stills) has been achieved after modifying the conventional double slope solar still by replacing opaque FRP walls by transparent acrylic walls of equivalent thickness. The hourly variation of inner surface temperature of walls and glass covers, and total yield have been found similar to that of conventional stills (9-10). Hence the thermal modeling designed for MDSSS can be used to test its performance for different operational and climatic parameters. The climatic conditions like ambient temperature and Solar Radiation adversely affect the yield from the solar still. During winter condition some arrangements are necessary to be incorporated to increase the productivity of the still.

\section{NOMENCLATURE}
$\mathrm{A}_{\mathrm{b}}$
Basin area $\left(\mathrm{m}^{2}\right)$
$\mathrm{A}_{\mathrm{gE}}$
glass cover Area (East) $\left(\mathrm{m}^{2}\right)$

$\mathrm{A}_{\mathrm{gw}}$

$\mathrm{A}_{\mathrm{E}}$

dt

$\mathrm{A}_{\mathrm{W}}$

$\mathrm{A}_{\mathrm{S}}$

$\mathrm{A}_{\mathrm{N}}$

$\mathrm{I}(\mathrm{t})_{\mathrm{gN}}$

$\mathrm{I}(\mathrm{t})_{\mathrm{gE}}$

$\mathrm{I}(\mathrm{t})_{\mathrm{gW}}$

$\mathrm{I}(\mathrm{t})_{\mathrm{acE}}$

$\mathrm{I}(\mathrm{t})_{\mathrm{acW}}$

$\mathrm{I}(\mathrm{t})_{\mathrm{acS}}$

$\mathrm{T}_{\mathrm{a}}$

$\mathrm{T}_{\mathrm{v}}$

$\mathrm{T}_{\mathrm{w}}$

$\mathrm{T}_{\mathrm{b}}$

$\mathrm{T}_{\mathrm{iE}}$

$\mathrm{T}_{\mathrm{iW}}$

$\mathrm{T}_{\mathrm{iS}}$

$\alpha_{\mathrm{g}}$

$\alpha_{E}^{\prime}$

$\alpha_{\mathrm{W}}$

C

$\mathrm{dt}_{\mathrm{w}} / \mathrm{dt}$

$\mathrm{h}_{\mathrm{ba}}$

$\mathrm{h}_{\mathrm{bw}}$

$\mathrm{h}_{\mathrm{go}}$

$\mathrm{h}_{\mathrm{aco}}$

$\mathrm{h}_{\mathrm{Kg}}$

$\mathrm{h}_{\text {Kacr }}$

$\mathrm{h}_{\mathrm{KFRP}}$

$\mathrm{h}_{\mathrm{s}}$

$\mathrm{h}_{\mathrm{o}}$

$\mathrm{h}_{\mathrm{vW}}$

$\mathrm{h}_{\mathrm{vS}}$

$\mathrm{h}_{\mathrm{vgE}}$

$\mathrm{h}_{\mathrm{vgW}}$

$\mathrm{h}_{\mathrm{evE}}$

$\mathrm{h}_{\mathrm{vE}}$

$\mathrm{T}_{\text {giW }}$ glass cover Area (West) $\left(\mathrm{m}^{2}\right)$

Wall Area (East) $\left(\mathrm{m}^{2}\right)$

Small time interval (s)

Wall Area (West) $\left(\mathrm{m}^{2}\right)$

Wall Area (South) $\left(\mathrm{m}^{2}\right)$

Wall Area (North) $\left(\mathrm{m}^{2}\right)$

Solar Flux ( north wall) $\left(\mathrm{W} / \mathrm{m}^{2}\right.$ )

Solar Flux (East Glass Cover) $\left(\mathrm{W} / \mathrm{m}^{2}\right)$

Solar Flux (West glass cover) $\left(\mathrm{W} / \mathrm{m}^{2}\right)$

Solar Flux ( East wall) $\left(\mathrm{W} / \mathrm{m}^{2}\right.$ )

Solar Flux (west wall) $\left(\mathrm{W} / \mathrm{m}^{2}\right)$

Solar Flux (south wall) $\left(\mathrm{W} / \mathrm{m}^{2}\right)$

Ambient air temperature $\left({ }^{\circ} \mathrm{C}\right)$

Vapor temperature $\left({ }^{\circ} \mathrm{C}\right)$

Water temperature $\left({ }^{\circ} \mathrm{C}\right)$

Basin temperature $\left({ }^{\circ} \mathrm{C}\right)$

Inner wall temperature of east side $\left({ }^{\circ} \mathrm{C}\right)$

Inner wall temperature of west side $\left({ }^{\circ} \mathrm{C}\right)$

Inner wall temperature of south side $\left({ }^{\circ} \mathrm{C}\right)$

Radiation absorption factor for toughened glass

Radiation absorption factor for East wall

Radiation absorption factor for west wall

Specific heat of water $\left(\mathrm{J} / \mathrm{Kg}{ }^{\circ} \mathrm{C}\right)$

Change in water temp. In small time $\left({ }^{\circ} \mathrm{C} / \mathrm{s}\right)$

Coefficient of conductive heat transfer from basin to ambient $\left(\mathrm{W} / \mathrm{m}^{2}{ }^{\circ} \mathrm{C}\right)$

Coefficient of Convective heat transfer from basin to water $\left(\mathrm{W} / \mathrm{m}^{2}{ }^{\circ} \mathrm{C}\right)$

Coefficient of combined convective and radiative heat transfer from inner surface of glass cover to ambient $\left(\mathrm{W} / \mathrm{m}^{2}{ }^{\circ} \mathrm{C}\right)$

Coefficient Combined convective and radiative heat transfer from inner surface of acrylic wall to ambient $\left(\mathrm{W} / \mathrm{m}^{2}{ }^{\circ} \mathrm{C}\right)$

Coefficient of Conductive heat transfer of glass cover $\left(\mathrm{W} / \mathrm{m}^{2}{ }^{\circ} \mathrm{C}\right)$

Coefficient of conductive heat transfer of acrylic wall $\left(\mathrm{W} / \mathrm{m}^{2}{ }^{\circ} \mathrm{C}\right)$

Coefficient of Conductive heat transfer of $\operatorname{FRP}\left(\mathrm{W} / \mathrm{m}^{2}{ }^{\circ} \mathrm{C}\right)$

Coefficient of convective heat transfer of side wall $\left(\mathrm{W} / \mathrm{m}^{2}{ }^{\circ} \mathrm{C}\right)$

$h_{0} \quad$ Coefficient of total convective and radiative heat transfer from wall and glass cover to ambient $\left(\mathrm{W} / \mathrm{m} 2{ }^{\circ} \mathrm{C}\right)$

Coefficient of total internal heat transfer from vapor to west wall $\left(\mathrm{W} / \mathrm{m}^{2}{ }^{\circ} \mathrm{C}\right)$

Coefficient of total internal heat transfer from vapor to South wall $\left(\mathrm{W} / \mathrm{m}^{2}{ }^{\circ} \mathrm{C}\right)$

Coefficient of total internal heat transfer from vapor to east glass cover $\left(\mathrm{W} / \mathrm{m}^{2}{ }^{\circ} \mathrm{C}\right)$

Coefficient of total internal heat transfer from vapor to west glass cover $\left(\mathrm{W} / \mathrm{m}^{2}{ }^{\circ} \mathrm{C}\right)$

Coefficient of Internal evaporative heat transfer from vapor to east wall $\left(\mathrm{W} / \mathrm{m}^{2}{ }^{\circ} \mathrm{C}\right)$ Coefficient of total internal heat transfer from vapor to east wall $\left(\mathrm{W} / \mathrm{m} 2{ }^{\circ} \mathrm{C}\right)$

Inner glass cover temperature of west side $\left({ }^{\circ} \mathrm{C}\right)$ 


$$
\begin{array}{ll}
\mathrm{T}_{\text {wo }} & \text { Temperature of basin water at time } \mathrm{t}=0\left({ }^{\circ} \mathrm{C}\right) \\
\mathrm{v} & \text { velocity of wind }(\mathrm{m} / \mathrm{s})
\end{array}
$$

\section{REFERENCES}

[1] G.N. Tiwari and A. Tiwari, Solar Distillation Practice for Water Desalination Systems, Anamaya, New Delhi, 2007.

[2] H.P. Garg and H.S. Mann, Effect of climatic, operational and design parameters on the year round performance of single-sloped and double- sloped solar still under Indian arid zone conditions, Solar Energy, 18 (1976) 159-163.

[3] G.N. Tiwari, C. Sumegha and Y.P. Yadav, Effect of water depth on the transient performance of a double basin solar still, Energy Conv. Manage., 32 (1991) 293301.

[4] D. Mowla and G. Karimi, Mathematical modeling of solar stills in Iran, Solar Energy, 55 (1995) 389-393.

[5] R.V. Dunkle, Solar water distillation : The roof type still and multiple effect diffusion solar still , Int. Dev. Heat Trans., ASME proceedings,(part 5): 895902,1961 .

[6] A.K. Tiwari, G.N. Tiwari, Desalination 180 (2005) 7388.

[7] V. K. Dwibedi, G.N. Tiwari, Experimental validation of thermal model of a double slope active solar still under natural circulation mode, Desalination 250(2010) 49-55.

[8] S.K. Shukla, V.P.S. Sorayan, Renewable Energy 30 (2005) 683-699.

[9] R. Dev, G.N. Tiwari, Desalination 245 (2009) 246-265.

[10]R. Dev, Thermal modeling and characteristic equation for passive and active solar stills, $\mathrm{PhD}$ Thesis, Center for Energy Studies, IIT Delhi, New Delhi, India (2012) 23-24.

[11] A.K. Nayak, Thermal Modelling and Parametric Study of Modified Double Slope Solar Still, IJAEST-V4N03274-281

\section{BIOGRAPHIES}

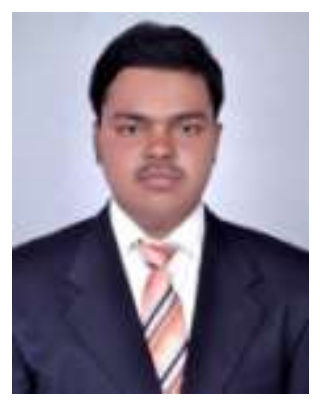

Mr. Ajaya Ketan Nayak is recently working as assistant professor in the school of mechanical Engineering in KIIT University, Bhubaneswar, odisha. He has achieved Gold Medal in M.Tech in Mechanical Engineering from Motilal Neheru National Institute of Technology, Allahabad in June 2014. He is currently involved in development of Modified Double Slope Distillation Systems. His area of research mainly includes Solar Thermal Technology, Passive and Active Solar Distillation, Sea water Desalination and Membrane distillation. He is also working on the technology of combining the Power generation and Desalination using Solar Energy under one unit.

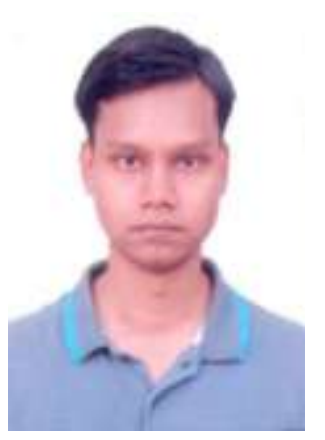

Mr. Rahul Dev is currently working as assistant professor in depart of mechanical engineering in Motilal Neheru National Institute of Technology. $\mathrm{He}$ is an eminent researcher in the field of solar energy and Solar thermal technology. He has completed his Phd. from IIT Delhi in 2012. He is involved in so many research projects (govt undertaking and also consultancy). His area of research includes Solar Energy Applications, Renewable Energy, Solar Passive Architecture etc. 